\title{
Crossing the Wall: Characterization of the Multiheme Cytochromes Involved in the Extracellular Electron Transfer Pathway of Thermincola ferriacetica
}

\author{
Marisa M. Faustino (D), Bruno M. Fonseca, Nazua L. Costa (D), Diana Lousa, Ricardo O. Louro \\ and Catarina M. Paquete *
}

check for updates

Citation: Faustino, M.M.; Fonseca, B.M.; Costa, N.L.; Lousa, D.; Louro, R.O.; Paquete, C.M. Crossing the Wall: Characterization of the Multiheme Cytochromes Involved in the Extracellular Electron Transfer Pathway of Thermincola ferriacetica. Microorganisms 2021, 9, 293. https://doi.org/10.3390/ microorganisms 9020293

Academic Editor: Xiaobo Liu Received: 31 December 2020 Accepted: 27 January 2021 Published: 31 January 2021

Publisher's Note: MDPI stays neutral with regard to jurisdictional claims in published maps and institutional affiliations.

Copyright: (C) 2021 by the authors. Licensee MDPI, Basel, Switzerland. This article is an open access article distributed under the terms and conditions of the Creative Commons Attribution (CC BY) license (https:/ / creativecommons.org/licenses/by/ $4.0 /)$.
Instituto de Tecnologia Química e Biológica António Xavier, Universidade Nova de Lisboa, Av. da República, 2780-157 Oeiras, Portugal; marisa.mfaustino@gmail.com (M.M.F.); bfonseca@itqb.unl.pt (B.M.F.); nazuacosta@itqb.unl.pt (N.L.C.); dlousa@itqb.unl.pt (D.L.); louro@itqb.unl.pt (R.O.L.)

* Correspondence: cpaquete@itqb.unl.pt; Tel.: +351-214469321

\begin{abstract}
Bioelectrochemical systems (BES) are emerging as a suite of versatile sustainable technologies to produce electricity and added-value compounds from renewable and carbon-neutral sources using electroactive organisms. The incomplete knowledge on the molecular processes that allow electroactive organisms to exchange electrons with electrodes has prevented their real-world implementation. In this manuscript we investigate the extracellular electron transfer processes performed by the thermophilic Gram-positive bacteria belonging to the Thermincola genus, which were found to produce higher levels of current and tolerate higher temperatures in BES than mesophilic Gram-negative bacteria. In our study, three multiheme $c$-type cytochromes, Tfer_0070, Tfer_0075, and Tfer_1887, proposed to be involved in the extracellular electron transfer pathway of T. ferriacetica, were cloned and over-expressed in E. coli. Tfer_0070 (ImdcA) and Tfer_1887 (PdcA) were purified and biochemically characterized. The electrochemical characterization of these proteins supports a pathway of extracellular electron transfer via these two proteins. By contrast, Tfer_0075 (CwcA) could not be stabilized in solution, in agreement with its proposed insertion in the peptidoglycan wall. However, based on the homology with the outer-membrane cytochrome OmcS, a structural model for CwcA was developed, providing a molecular perspective into the mechanisms of electron transfer across the peptidoglycan layer in Thermincola.
\end{abstract}

Keywords: Thermincola; multiheme c-type cytochromes; extracellular electron transfer; electroactive organisms; Gram-positive bacteria

\section{Introduction}

Extracellular electron transfer (EET) is a metabolic process that allows microorganisms to exchange electrons with external conductive solids, including metal oxides in their natural environment and electrodes in bioelectrochemical systems (BES) [1,2]. Microorganisms capable of producing electricity were reported more than one century ago [3]. The ability of these microorganisms to exchange electrons with electrodes earned the designation of electroactive but only recently their EET mechanisms have been explored in detail [1,4-7]. There is a great interest in understanding the EET mechanisms of electroactive organisms due to their capacity to produce electricity and added-value products from renewable and carbon-neutral sources (e.g., municipal wastewater), under ambient temperature and pressure and with low greenhouse gas emissions contributing to tackle numerous societal challenges including clean energy and global warming [8-12].

Currently, more than 100 organisms are known to be electroactive [2,13]. Among these, the thermophilic iron-reducing bacterium Thermincola potens strain JR, identified in a microbial fuel cell (MFC) operating at high temperatures $\left(55^{\circ} \mathrm{C}\right)$, was shown to produce higher levels of current than the well-studied mesophilic Gram-negative electroactive 
bacteria Geobacter sulfurreducens and Shewanella oneidensis MR-1 (0.42 mA versus $0.25 \mathrm{~mA}$ and 0.03-0.30 mA for Geobacter and Shewanella respectively, in the same type of MFC) [14]. Since BES operating at high temperatures enable the production of higher current densities and allow higher chemical oxygen demand (COD) removal [14-16], the understanding of the EET processes performed by these thermophilic electroactive organisms has gained impetus in recent years [16-18].

T. potens JR shares 99\% sequence similarity with T. ferriacetica [19], that was the first Gram-positive bacterium found to perform direct electron transfer to an electrode in BES $[20,21]$. Since T. ferriacetica grows at faster rates and to higher optical densities than $T$. potens $[19,22]$, this strain has been considered a more promising organism for investigation within its genus. Indeed, T. ferriacetica produces thicker biofilms (>150 $\mu \mathrm{m})$ and has a higher surface area for connecting with the electrode, which results in higher current densities when compared with T. potens [23,24]. Furthermore, the presence of a conductive extracellular matrix in T. ferriacetica $[17,23,25]$ and the absence of one in T. potens suggests that this species may have redox active proteins in the extracellular matrix as observed for Geobacter [26,27].

Electroactive organisms contain specific pathways to establish electrical contact between intracellular carriers and the cell surface $[7,28,29]$. The current state of the art shows multiheme c-type cytochromes (MHC) as key players in these pathways, transferring electrons across the cell envelope of numerous bacteria [28-30]. EET can occur through direct contact between the MHC and the external electron donor or acceptor [18,31-34], or indirectly, where soluble electron shuttles (e.g., flavins, quinones) mediate electron transfer between the cell and the terminal electron acceptor [35-39].

In T. potens, an EET pathway composed by four MHC was proposed to transfer electrons to extracellular acceptors [34]. These proteins are conserved between the two Thermincola species: TherJR_1117 (Tfer_0070 in T. ferriacetica) that contains 10 heme binding motifs ( $\mathrm{CXXCH}$, where $\mathrm{X}$ is any amino acid) and is predicted to be anchored to the membrane; TherJR_0333 (Tfer_1887) that also contains 10 heme binding sites and is located in the periplasm; TherJR_1122 (Tfer_0075) that contains six heme binding motifs and is proposed to be embedded in the peptidoglycan cell-wall; and TherJR_2595 (Tfer_3193) that has 9 heme binding sites and is located at the cell surface. The structure and functional mechanisms of the cell-surface MHC OcwA from T. potens (TherJR_2595) were elucidated, demonstrating that this protein can transfer electrons to an electrode and reduce soluble electron shuttles and oxyanions [18]. Furthermore, the structure of OcwA showed that the overall fold and organization of the hemes is more similar to MHC involved in the biogeochemical cycles of nitrogen and sulfur [18], instead of cell-surface MHC of Shewanella and Geobacter genera involved in EET [33,40].

To characterize the proposed EET pathway of Thermicola $s p$., we have cloned and heterologously expressed the MHC from T. ferriacetica in Escherichia coli, hereafter referred to as: Inner-membrane decaheme cytochrome A (ImdcA, Tfer_0070), Periplasmic decaheme cytochrome A (PdcA, Tfer_1887) and Cell-wall cytochrome A (CwcA, Tfer_0075). The purification of ImdcA and PdcA along with their electrochemical and biochemical characterization, supports a pathway of EET via these two proteins. Sequence homology modelling was used to propose the three-dimensional architecture of CwCA, showing a novel potential pathway for electrons to be transferred across the thick peptidoglycan cell-wall of Thermincola sp.

\section{Materials and Methods}

\subsection{Bacterial Strains and Growth Conditions}

\subsubsection{ImdcA}

The gene imdcA (Tferr_0070, NZ_LGTE01000001.1) was synthesized (NZYTech, Lisbon, Portugal) and amplified using the primers Forw_Tfer0070 and Rev_Tfer0070 presented in Table S1. Cloning into the expression vector pBAD/Thio-TOPO (Invitrogen, Carlsbad, CA, USA) was achieved using the methodology described by the manufacturer. To facilitate 
protein purification, the C-terminal polyhistidine $(6 \times$ His $)$ tag present in the plasmid was replaced by a Strep-tag ${ }^{\circledR}$ (WSHPQFEK aminoacid sequence) through site-directed mutagenesis using the primers strep_forw and strep_rev listed in Table S1. The resulting plasmid was transformed in E. coli JM109(DE3) strain, previously transformed with the vector pEC86 that encodes the cytochrome $c$ maturation system $(\mathrm{Ccm})$. These cells were then grown aerobically at $37^{\circ} \mathrm{C}$ and $150 \mathrm{rpm}$ in an Erlenmeyer flask with $2 / 5$ of its capacity filled with Terrific Broth (TB) medium supplemented with $34 \mu \mathrm{g} \mathrm{mL}^{-1}$ chloramphenicol and $100 \mu \mathrm{g} \mathrm{mL}^{-1}$ ampicillin. A $1 \%$ inoculum of cells grown overnight under the same conditions was used to initiate growth. Protein expression was induced by the addition of $1 \mathrm{mM}$ of L-arabinose at mid-exponential phase (after approximately $6 \mathrm{~h}$ of growth), and the cells were allowed to grow for another $16 \mathrm{~h}$ at $30{ }^{\circ} \mathrm{C}$. The cells were then harvested by centrifugation at $11,300 \times g$ for $8 \mathrm{~min}$ at $4{ }^{\circ} \mathrm{C}$.

\subsubsection{PdcA}

The plasmid pBAD202/D-TOPO harboring $p d c A$ gene (Tfer_1887, LGTE01000012.1) was obtained through site-directed mutagenesis, using pBAD202/D-TOPO harboring TherJR_0333 [41] and the primers listed in Table S1 (Tfer1887_mutX_forw and Tfer1887_mutX_rev, where " $X$ " represents the number of the mutation). The resulting plasmid was transformed in E. coli BL21(DE3) previously transformed with vector $\mathrm{pEC} 86$. PdcA was expressed as described for ImdcA, however the TB medium was supplemented with $50 \mu \mathrm{g} \mathrm{mL}^{-1}$ kanamycin instead of ampicillin.

\subsubsection{CwcA}

The gene cwcA (Tferr_0075, NZ_LGTE01000001.1) was amplified and cloned in pBAD/ Thio-TOPO (Invitrogen) as described by the manufacturer and in [41] using the primers listed in Table S1 (Forw_STC_0075, Forw_STC_pBADthio, Rev_Tfer0075 and Rev_STC_0075). In this construct, the native signal peptide of CwcA was replaced by the signal peptide of the small tetraheme cytochrome (STC) from the Gram-negative S. oneidensis MR-1. The resulting plasmid was transformed in E. coli BL21(DE3) previously transformed with vector pEC86. CwcA was expressed as described for ImdcA. All constructs were confirmed by DNA sequencing (Eurofins, Ebersburg, Germany).

\subsection{Protein Purification}

2.2.1. ImdcA

To purify ImdcA the cell pellet was first resuspended in $20 \mathrm{mM}$ Tris- $\mathrm{HCl}$ buffer ( $\mathrm{pH}$ 9.0), containing EDTA-free Protease Inhibitor Cocktail (Merck, Mannheim, Germany) and DNase I (Merck), using a 1:1 ratio of cell wet weight to buffer volume. Cells were then lysed using a French press at a pressure of 1000 psi. To solubilize the proteins from the membranes, the membrane fraction, collected by centrifugation at $200,000 \times g$ for $1 \mathrm{~h}$ at $4{ }^{\circ} \mathrm{C}$, was resuspended in $20 \mathrm{mM}$ Tris- $\mathrm{HCl}$ buffer (pH 9.0) containing $100 \mathrm{mM} \mathrm{NaCl}$ and $2 \%$ SB-12, and left at $4{ }^{\circ} \mathrm{C}$ overnight with gentle stirring. This mixture was then centrifuged at $200,000 \times g$ for $1 \mathrm{~h}$ at $4{ }^{\circ} \mathrm{C}$, and the supernatant containing solubilized proteins was loaded in a Strep-Tacti ${ }^{\circledR}$ Superflow ${ }^{\circledR}$ high-capacity cartridge (IBA) previously equilibrated with $100 \mathrm{mM}$ Tris- $\mathrm{HCl}$ buffer ( $\mathrm{pH} 9.0$ ) containing $150 \mathrm{mM} \mathrm{NaCl}$ and $0.2 \% \mathrm{SB}-12$. The loaded sample was washed with the same buffer and eluted in buffer containing $5 \mathrm{mM}$ D-desthiobiotin (IBA, Göttingen, Germany). After elution, the proteins were dialyzed overnight in $20 \mathrm{mM}$ Tris- $\mathrm{HCl}$ buffer ( $\mathrm{pH}$ 9.0) with $100 \mathrm{mM} \mathrm{NaCl}$ and $0.2 \%$ SB-12 or $0.5 \%$ Triton X-100, and analyzed for protein purity by SDS-PAGE $12 \%$ and UV-visible spectroscopy.

\subsubsection{PdcA}

To purify PdcA the cells were resuspended in $200 \mathrm{mM}$ Tris-HCl buffer ( $\mathrm{pH} 7.6$ ) containing $0.5 \mathrm{M}$ sucrose, $0.5 \mathrm{mM}$ EDTA and $100 \mathrm{mg} \cdot \mathrm{L}^{-1}$ lysozyme and supplemented with EDTA-free protease inhibitor cocktail (Merck) and DNase I (Merck). This mixture was 
stirred for $1 \mathrm{~h}$ at $4{ }^{\circ} \mathrm{C}$. The periplasmic fraction was separated by centrifugation at $11,300 \times g$ for $8 \mathrm{~min}$ at $4^{\circ} \mathrm{C}$, and dialyzed in $50 \mathrm{mM}$ Tris- $\mathrm{HCl}$ buffer ( $\left.\mathrm{pH} 9.0\right)$ overnight at $4{ }^{\circ} \mathrm{C}$. The protein was precipitate at room temperature using a gradient (20\% to $50 \%$ ) of an ammonium sulfate concentrated solution ( $3.5 \mathrm{M}$ ) (Sigma, Steinheim, Germany). After each salt addition the precipitate was collected by centrifugation at $5000 \times g$ for $5 \mathrm{~min}$. Each pellet was solubilized in $20 \mathrm{mM}$ Tris $\mathrm{HCl}$ buffer ( $\mathrm{pH}$ 9.0) containing $100 \mathrm{mM} \mathrm{KCl}$ and $10 \mathrm{mM}$ sodium cholate, and analyzed by SDS-PAGE $12 \%$ to select the fraction that contained the desired protein. The fraction containing PdcA was precipitated at approximately $30 \%$ of ammonium sulfate. This fraction was then dialyzed overnight in $20 \mathrm{mM}$ Tris $\mathrm{HCl}$ buffer ( $\mathrm{pH}$ 9.0) with $10 \mathrm{mM}$ sodium cholate, to prevent precipitation of the target protein [41], and loaded onto a Q-sepharose HP column (GE Healthcare, Uppsala, Sweden) previously equilibrated with the same buffer and a salt gradient from 0 to $1 \mathrm{M}$ was applied. The PdcA protein was eluted in the flow through. The fractions were analyzed for protein purity by SDS-PAGE $12 \%$ and UV-visible spectroscopy.

\subsection{Mass Spectrometry}

The protein solution was desalted and concentrated using POROS C8 (3 M Empore, St. Paul, MN, USA) and eluted directly onto the MALDI plate using $0.6 \mu \mathrm{L}$ of $10 \mathrm{mg} \cdot \mathrm{mL}^{-1}$ Sinapic acid (Sigma) in 50\% $(v / v)$ acetonitrile and 5\% $(v / v)$ formic acid (LC/MS grade, Fisher, Hampton, NH, USA). The data was acquired in Linear Mid Mass Positive mode using a 5800 MALDI-TOF/TOF mass spectrometer (AB Sciex, Framingham, MA, USA) and TOF/TOF Series Explorer Software v.4.1.0 (AB Sciex). External calibration was performed using Protein MALDI-MS Calibration Kit (MSCAL3, ProteoMass, Merck).

\subsection{Spectroscopic Techniques}

\subsubsection{UV Visible Spectroscopy}

UV-visible spectra of ImdcA and PdcA were recorded in a UV-1800 spectrophotometer (Shimadzu, Gamby, OR, USA) in the 250 to $750 \mathrm{~nm}$ wavelength range. While PdcA was prepared in $20 \mathrm{mM}$ Tris-HCl buffer ( $\mathrm{pH}$ 9.0) containing $100 \mathrm{mM} \mathrm{KCl}$ and $10 \mathrm{mM}$ sodium cholate, ImdcA was prepared in $20 \mathrm{mM}$ Tris- $\mathrm{HCl}$ buffer ( $\mathrm{pH}$ 9.0) containing $100 \mathrm{mM} \mathrm{NaCl}$ and $0.2 \%$ SB12. UV-visible spectra were acquired for both the oxidized and the reduced state of the proteins. The reduction of the proteins was obtained by the addition of sodium dithionite.

\subsubsection{EPR Spectroscopy}

For the EPR experiments the ImdcA solution was prepared in $20 \mathrm{mM}$ potassium phosphate buffer ( $\mathrm{pH} 9$ ) with $100 \mathrm{KCl}$ and $0.5 \%$ Triton $\mathrm{X}-100$, and PdcA prepared in $20 \mathrm{mM}$ Tris- $\mathrm{HCl}$ buffer ( $\mathrm{pH}$ 9) containing $50 \mathrm{mM} \mathrm{KCl}$ and $10 \mathrm{mM}$ sodium cholate. EPR spectra were recorded on a Bruker ESP 380 spectrometer equipped with an ESR 900 continuousflow helium cryostat (Oxford Instruments, Oxfordshire, UK) The conditions used in these experiments were: a temperature of $7 \mathrm{~K}$ and $18 \mathrm{~K}$ for ImdcA and PdcA, respectively; a microwave frequency of $9.39 \mathrm{GHz}$; an amplitude modulation of $1.0 \mathrm{mT}$; and a microwave power of $2 \mathrm{~mW}$.

\subsubsection{NMR Spectroscopy}

1H-1D-NMR spectra were collected at $25^{\circ} \mathrm{C}$ on an Avance II+ $500 \mathrm{MHz}$ NMR spectrometer (Bruker, Rheinstetten, Germany) equipped with a $5 \mathrm{~mm}$ TCI C/N Prodigy Cryo probe. The ImdcA sample was prepared in $20 \mathrm{mM}$ Tris- $\mathrm{HCl}$ buffer ( $\mathrm{pH}$ 9.0) containing $100 \mathrm{mM} \mathrm{NaCl}$ and $0.2 \%$ SB12 containing $10 \%{ }^{2} \mathrm{H}_{2} \mathrm{O}(99.9$ atom $\%)$, while the PdcA sample was prepared in $20 \mathrm{mM}$ Tris- $\mathrm{HCl}$ buffer ( $\mathrm{pH}$ 9.0) with $100 \mathrm{mM} \mathrm{KCl}$ and $10 \mathrm{mM}$ sodium cholate containing $10 \%{ }^{2} \mathrm{H}_{2} \mathrm{O}(99.9$ atom $\%)$. For solvent suppression and enhancement of the paramagnetic signals, a SuperWEFT pulse sequence was applied. The NMR spectra were processed and analyzed using Bruker TopSpin 4.0 software. 


\subsection{Electrochemical Measurements of $P d c A$ and $\operatorname{Imdc} A$}

Electrochemical measurements were carried out at $25^{\circ} \mathrm{C}$ using a single chamber threeelectrode system cell configuration consisting of a pyrolytic graphite edge (PGE) working electrode (IJ Cambria Scientific, Llanelli, UK), an $\mathrm{Ag} / \mathrm{AgCl}(3 \mathrm{M} \mathrm{KCl})$ reference electrode (IJ Cambria Scientific) and a graphite rod counter electrode (P46101-CMG, Morganite Luxembourg S.A., Luxembourg). Cyclic voltammetry (CV) experiments were acquired in a Autolab PGSTAT2014 potentiostat (Metrohom Autolab s.v., Utrecht, The Netherlands). Prior to use, the PGE electrode was polished with aqueous $\mathrm{Al}_{2} \mathrm{O}_{3}$ slurry $(1.0 \mu \mathrm{m})$, rinsed with water, and dried with a tissue before being exposed to the protein. The proteins were deposited on the surface of the working electrode by drying $1 \mu \mathrm{L}$ of each protein sample $(50 \mu \mathrm{M})$ with constant gas nitrogen flow. The buffers used in these experiments were prepared by mixing $5 \mathrm{mM}$ of HEPES (Sigma Aldrich), $5 \mathrm{mM}$ of MES (Sigma Aldrich) and $5 \mathrm{mM}$ of TAPS (Sigma Aldrich) and $100 \mathrm{mM} \mathrm{KCl}$. The desired $\mathrm{pH}$ values were adjusted with $1 \mathrm{M} \mathrm{NaOH}$ or $\mathrm{HCl}$ solutions. The $\mathrm{CV}$ experiments were acquired three times in the scan range of $-800 \mathrm{mV}$ to $+200 \mathrm{mV}$ (vs. $\mathrm{Ag} / \mathrm{AgCl} 3 \mathrm{M} \mathrm{KCl}$ ). The baseline was obtained in similar conditions but without depositing the protein on the electrode. QSoas program (version 1.0) available at https:/ / bip.cnrs.fr/groups/bip06/software/ [42] was used to subtract the capacitive current and suppress background noise of the raw electrochemical data. All potentials are reported with respect to a standard hydrogen electrode (SHE) by addition of $210 \mathrm{mV} \mathrm{[43]} \mathrm{to} \mathrm{those} \mathrm{measured.}$

\subsection{Homology-Based Modelling}

\subsubsection{CwcA}

The structural model of CwcA was generated using the cryoelectron microscopy structure of cytochrome OmcS from G. sulfurreducens as a template (PDB code: 6EF8) [33]. This template was chosen because it has the highest sequence identity with the target among proteins with known structure (18\% sequence identity) (Figure S1). The first 5 and the last 12 residues of CwcA were not modelled since they did not align with the template. A sequence alignment generated with the Robetta webserver (http://new.robetta.org/) was used as input to build the model, after manual curation to ensure that all the heme binding motifs were aligned. The model was built using the automodel class implemented in Modeller (version 9.22) [44] with the refinement degree set to slow. The final model corresponds to the one with the lowest value of the objective function, out of 20 generated structures. To analyze how CwcA monomers interact with each other, a model containing 3 adjacent protein molecules based on the template structure was built.

\subsubsection{OcwA}

The structural model of OcwA from T. ferriacetica (Tfer_3193) was generated using the structure of OcwA from T. potens as a template (PDB code: 6I5B) [18]. Given that the two sequences have a very high sequence identity $(99 \%)$, only the aminoacid residues that differ between the two proteins (three aminoacids from the holo-protein) were optimized, while the rest of the structure was considered to be identical to the template (Figure S2). The model was built using a mutation class implemented in Modeller (version 9.22) [44], which mutates and optimizes selected residues. The final model corresponds to the one with the lowest value of the objective function, out of 20 generated structures.

\section{Results}

\subsection{Production of MHC Involved in EET of T. ferriacetica}

The MHC ImdcA, PdcA and CwcA from T. ferriacetica were successfully cloned into expression vectors and heterologously over-expressed in the Gram-negative bacterium E. coli. While ImdcA and PdcA were further purified, CwcA could only be obtained in an insoluble state. The hexaheme cytochrome CwcA was extracted from the membrane fraction with urea under denaturating conditions, however its refolding was never achieved in solution. ImdcA was purified from the membrane fraction, while PdcA was isolated 
from the soluble fraction of E. coli. Recombinant proteins gave a single band in the SDSPAGE gels between 35 and $48 \mathrm{kDa}$ markers stained with Coomassie, demonstrating that both proteins were isolated from other cellular components (Figure S3).

As expected for a protein associated with the inner-membrane, the $\mathrm{N}$-terminal sequence for ImdcA (GIRD) showed that the signal peptide was not cleaved (Figure S4a). For $\mathrm{PdcA}$, the $\mathrm{N}$-terminal sequence (TAPEK) indicated that the protein was correctly processed in E. coli, with the signal peptide being cleaved in the position expected for processing in the native organism (Figure S4b).

Mass spectrometry showed that the purified proteins have molecular masses of $\sim 47.5 \mathrm{kDa}$ and $42.6 \mathrm{kDa}$ for ImdcA and PdcA, respectively, which agree with the calculated molecular mass of the apo-proteins $(41.7 \mathrm{kDa}$ and $36.5 \mathrm{kDa}$ for ImdcA and PdcA, respectively) with the incorporation of the 10 hemes ( $\sim .6 \mathrm{kDa}$ per each heme). UV-visible spectra of both proteins showed the typical features of $c$-type cytochromes that contain hexacoordinated low-spin hemes (Figure 1a,b), with absorption peaks at $409 \mathrm{~nm}$ (Soret peak) and $530 \mathrm{~nm}$ in the oxidized state, and upon protein reduction, by the shift of the Soret peak to $421 \mathrm{~nm}$, and the appearance of the $\beta$ - and $\alpha$-band at 525 and $552 \mathrm{~nm}$, respectively.

(a) ImdcA

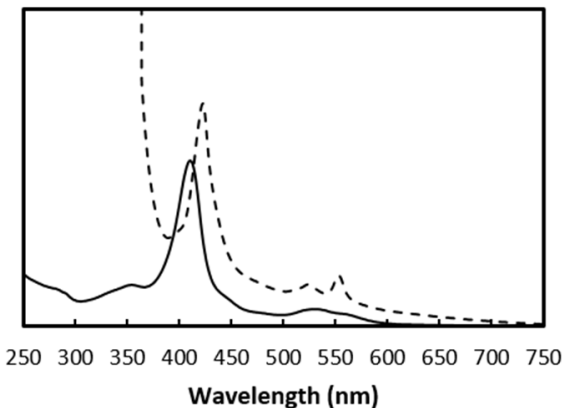

(c) ImdcA

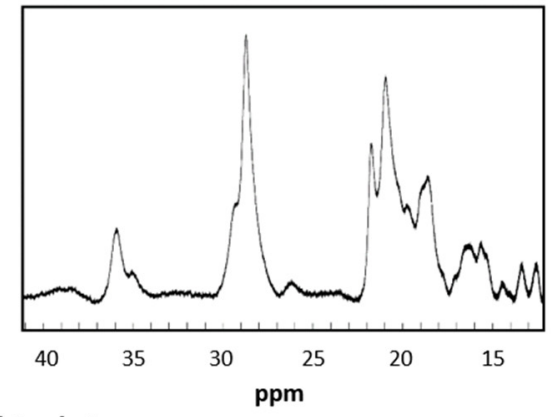

(e) ImdcA

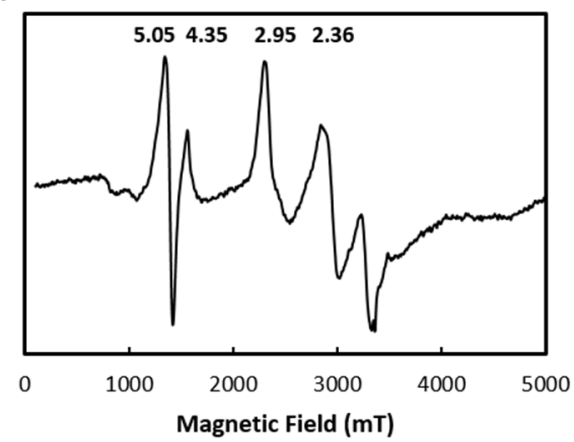

(b) PdcA

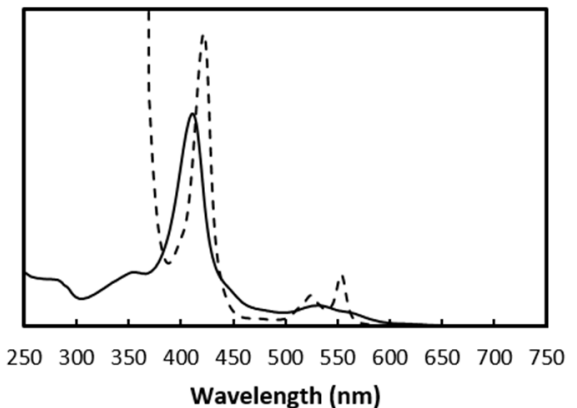

(d) PdcA

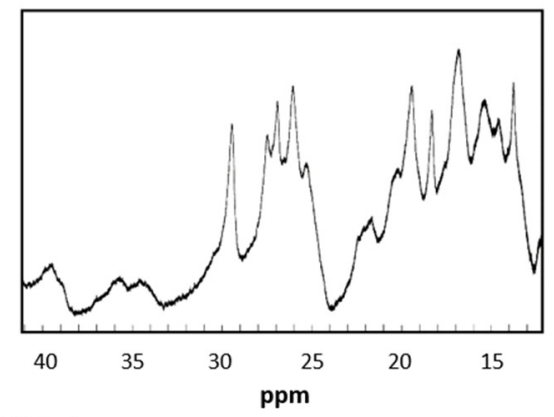

(f) PdcA

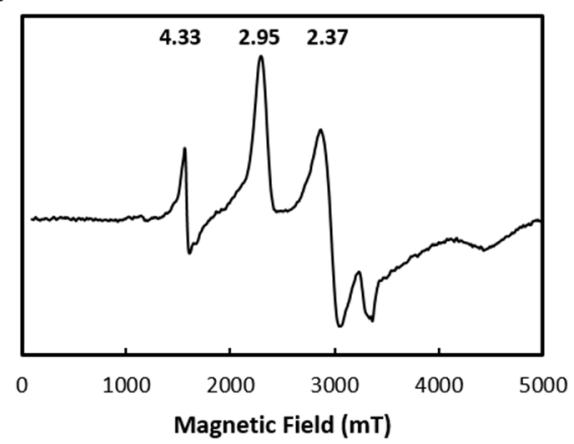

Figure 1. Spectroscopic characterization of ImdcA (left) and PdcA (right). (a,b) UV-visible spectra obtained in the oxidized (solid line) and reduced state (dotted line); (c,d) ${ }^{1} \mathrm{H}-1 \mathrm{D}$ NMR spectra obtained at $25{ }^{\circ} \mathrm{C}$ in the oxidized state; (e,f) EPR spectra obtained at $9.39 \mathrm{GHz}$ for the oxidized state. In both spectra, the signal at around $g=4.3$ is expected to derive from iron (III) adventitiously present in the sample. 
The ${ }^{1} \mathrm{H}-1 \mathrm{D}-\mathrm{NMR}$ spectra of both proteins in the oxidized state present signals outside the protein envelope, up to $40 \mathrm{ppm}$ (Figure 1c,d), which indicates the presence of typical low-spin hemes axially coordinated by strong-field ligands such as histidines or methionines.

The EPR spectrum of ImdcA shows signals with at $g_{\max }$ values of 2.95 and 2.36 (Figure 1e), while the spectrum of PdcA shows signals with $g_{\text {max }}$ values of 2.95 and 2.37 (Figure 1f). These are typical of hexacoordinated low-spin hemes with axial and rhombic electronic spin structure, that correlate with the presence of axial ligands of the iron that are parallel and perpendicular to each other, respectively [45]. ImdcA also contains a signal at $g=5.05$ which can be tentatively assigned to a high-spin heme Fe(III) species.

\subsection{Electrochemical Behavior of ImdcA and $P d c A$}

To study the redox properties of ImdcA and PdcA, purified proteins were adsorbed to the surface of a pyrolytic graphite "edge" electrode and CV were performed (Figure 2 and Figure S5). These data show that PdcA titrates at slightly lower reduction potentials when compared with ImdcA for the $\mathrm{pH}$ values tested, and that both proteins present redox-Bohr effect (i.e., the reduction potential of the redox centers changes with $\mathrm{pH}$ [46]) (Figure S5). This effect is usually observed in multicenter redox proteins, such as MHC $[18,47,48]$, facilitating the full reduction of the protein, since the uptake of protons balances the electrostatic repulsion that arises from taking up multiple electrons.

(a) ImdcA

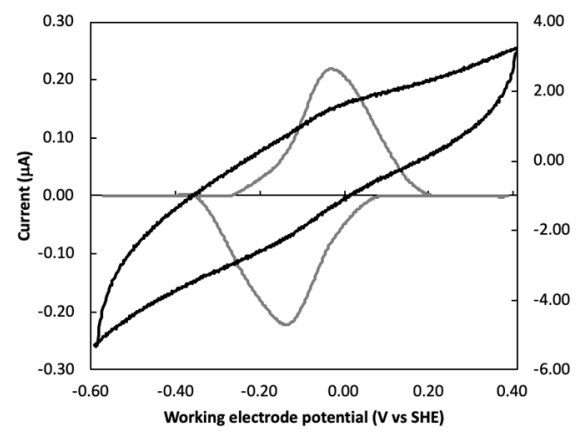

(b) PdcA

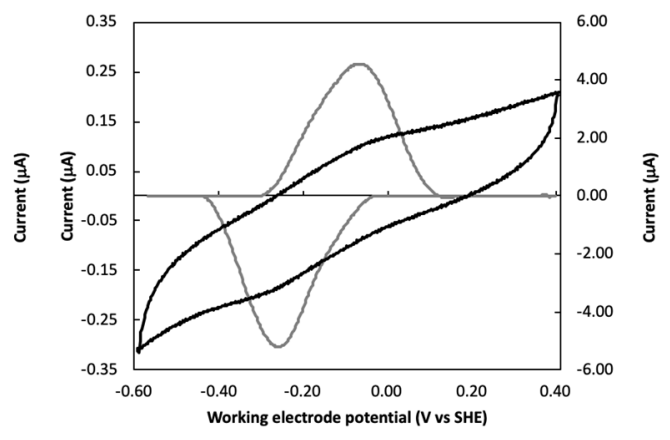

Figure 2. Cyclic voltammetry of (a) ImdcA and (b) PdcA: raw (black and right axis) and baselinesubtracted data (grey and left axis) of the voltammograms obtained at a scan rate of $200 \mathrm{mV} / \mathrm{s}$ at pH 6.

In a protein with multiple redox centers, as the case of ImdcA and PdcA, the voltammogram contains information about the redox behavior of each individual redox center [49]. The different shape observed for the voltammograms obtained at each $\mathrm{pH}$ indicate that the redox-Bohr effect does not impact the various hemes equally, as previously observed [50]. This is a consequence of the distance dependence of the electrostatic interaction between charged centers in MHC [51].

\subsection{Structural Model of CwcA}

The structure of cytochrome OmcS from G. sulfurreducens was used as a template to build a structural model of CwcA. Although the sequences of the two proteins have a modest identity (18\% of the residues are identical and $41 \%$ are either identical or have similar properties, Figure S1), the structures of two homologous MHC are usually considerably more conserved than the respective sequences $[52,53]$. The homology-based model of CwcA generated using the available structure of OmcS suggests that the protein can adopt a polymer-like structure similar to that observed in OmcS, where several protein molecules are stacked on top of each other forming a nanowire (Figure 3). Each CwcA molecule contains 6 hemes, coordinated by two histidines. This model indicates that one of the hemes (heme 5 in Figure 3) may be coordinated by a histidine belonging to a different cytochrome subunit, as occurs in OmcS of G. sulfurreducens [33]. The hemes in the protein 
model are packed within 3.5-6 $\AA$ of each other which is sufficiently close to guarantee fast intramolecular electron transfer along the polymer [47,54], a necessary requirement for efficient electron transfer within the respiratory pathway. Given the identity between the two sequences, the proposed model provides insights into the architecture and the mode of action of this protein, but does not to deliver a detailed prediction structure of CwCA. In the case of ImdcA and PdcA the homology with MHC of known structure was too low to support the calculation of structural models.

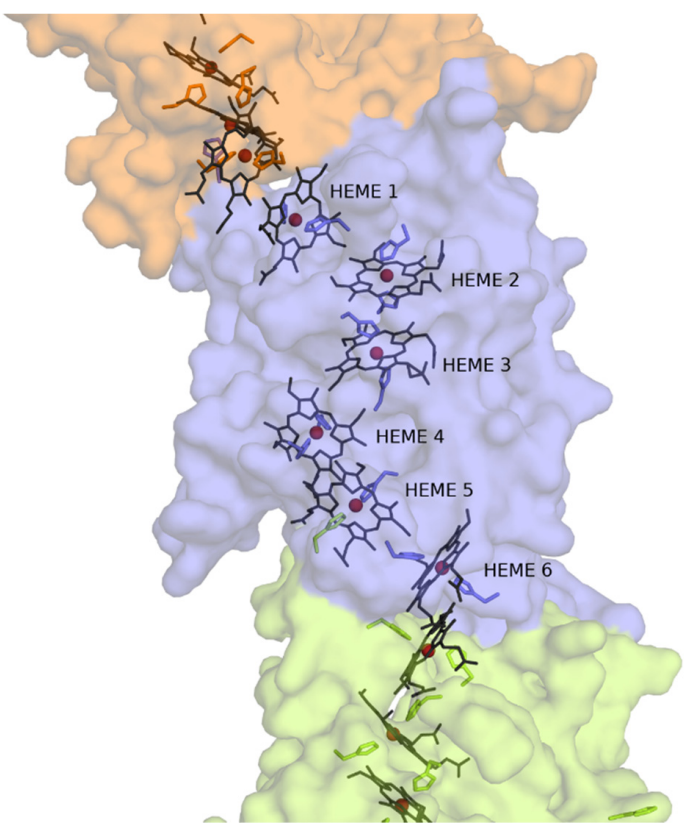

Figure 3. Homology-based model of the CwcA structure. Three CwcA molecules are displayed using molecular surface representations with different colors. The heme groups are represented as grey sticks with the Fe atoms displayed as dark red spheres and the coordinating histidines are represented as sticks of the same color as the respective molecular surface.

\section{Discussion}

In this work ImdcA and PdcA from T. ferriacetica were produced and biochemically characterized. The electrochemical characterization of ImdcA and PdcA shows that the window within which these proteins are electrochemically active spans more than $400 \mathrm{mV}$ (Figure 2). Although the complexity of the systems, with ten hemes in each protein, precludes the determination of the reduction potential of each individual heme by these methods $[7,49]$, it is clear from the electrochemical data that the distribution of the potentials of the various hemes differs, in particular with $\mathrm{pH}$ (Figure S5). Both proteins present spectroscopic properties typical of $c$-type cytochromes with hexacoordinated low-spin hemes, as observed for other MHC involved in EET pathways [18,27,47,48,53,55]. The aminoacid sequence of PdcA (Figure S4) suggests that only nine of the hemes are bishistidinyl axial coordinated, and that probably one heme may contain a methionine as the distal coordinated ligand. In contrast, although ImdcA contains enough histidines for all the hemes to be hexacoordinated with two histidines, the EPR spectrum suggests that one of the hemes may be high-spin. Indeed, high-spin hemes in inner-membrane MHC, such as ImdcA, are often involved in the interaction with quinones from the quinone pool in the inner-membrane $[56,57]$. The range of redox potentials in which ImdcA and PdcA are electrochemically active is similar to that of MHCs of other electroactive organisms and adequate to extract electrons from low-potential quinone pools such as menaquinones $[58,59]$. This fits with the proposal that ImdcA oxidizes the quinone pool in the membrane and transfers the electrons to the soluble decaheme cytochrome PdcA present in the periplasmic space [34]. PdcA can then transfer the electrons outside of the cell, to OcwA or external electron acceptors, through CwcA that is embedded in the peptidoglycan layer (see below). 
The experimental determination of the electrochemical active range of CwcA could not be obtained but the homology model showing bis-histidine axial coordination of the hemes suggests that the reduction potentials will be in a similar range to those observed for PdcA and ImdcA $[27,48]$. The high sequence homology between OcwA from T. potens and T. ferriacetica (520/525 aminoacids) argues that their mode of action, redox behaviour, as well as their structural properties are very similar (Figure S2). Overall, ImdcA, PdcA CwcA and OcwA are redox active in a similar range of electrochemical potential (between $+100 \mathrm{mV}$ to $-300 \mathrm{mV}$ vs. SHE). As observed for other electroactive organisms [48], this range provides the necessary electrochemical window to establish connection between the cell metabolism and extracellular acceptors of higher potential such as iron minerals, maintaining a favorable driving force along the whole chain.

CwcA was not purified in this work due to the difficulties in stabilizing the protein in a soluble form. This experimental observation supports the computational homology model showing CwcA as capable of forming long polymers as experimentally observed for OmcS. Based on this structural model, we propose that CwcA can be arranged with similar structural features within the peptidoglycan wall of the Gram-positive bacterium where several protein molecules are stacked on top of each other forming a nanowire (Figure 3). This arrangement allows the hemes to be close to each other, guaranteeing fast intramolecular electron transfer within the proteins across the cell-wall, and probably beyond. Since the thickness of the peptidoglycan can vary between 20 and $80 \mathrm{~nm}[16,24]$, around 4 to $16 \mathrm{CwcA}$ molecules can be arranged end to end to span the thickness of the cell-wall. This enables CwcA to emerge at the cell surface to transfer electrons to OcwA present at the cell surface, or directly to electron shuttles or insoluble electron acceptors. This fits with the current model of organization responsible for EET in Gram-positive bacteria belonging to the Thermincola genus [34,60] (Figure 4). A flavin-based transfer mechanism proposed for other Gram-positive bacteria [61] cannot be however excluded for this genus. Although this type of EET process has never been observed in Thermincola bacteria, genes involved in the flavinylation of proteins [62] are present in the genome of $T$. potens, suggesting that flavin mediated EET can also occur in Thermincola.

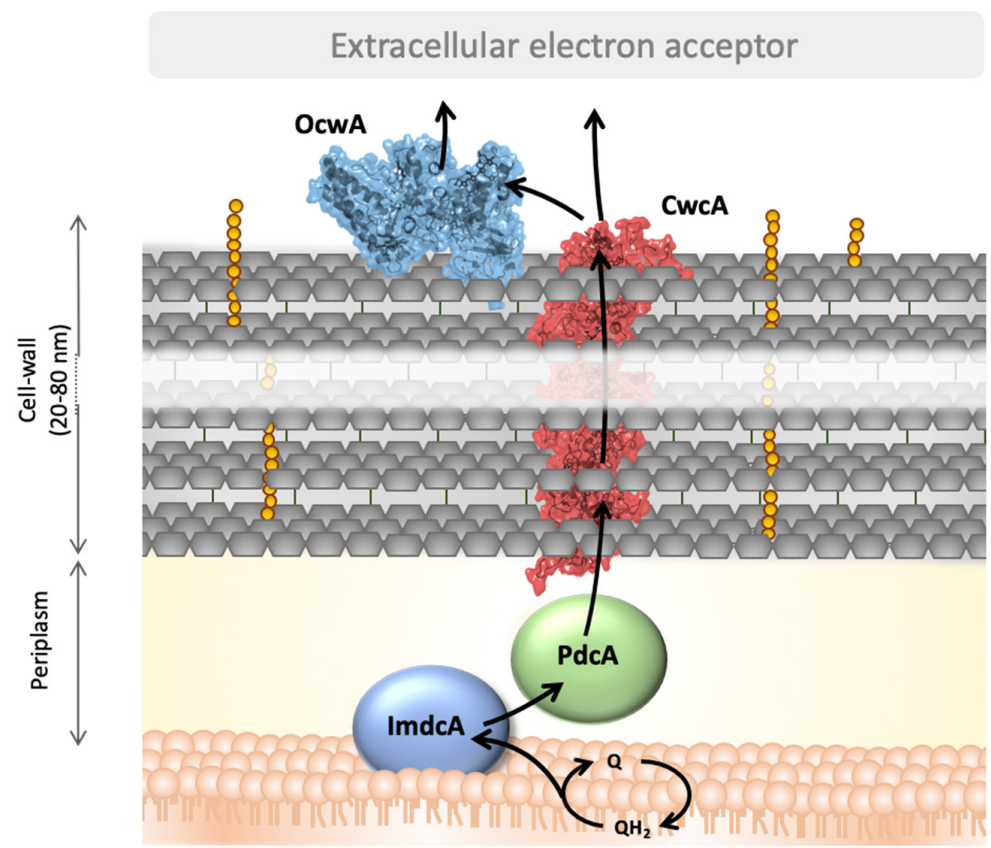

Figure 4. Representative scheme of the EET pathway of T. ferriacetica and the proteins involved. Cytochrome representations were made with PyMOL using the homology-based model of CwcA and OcwA. The correct orientation of both proteins is not known, and the scheme represents only one possibility of their position. MHC ImdcA and PdcA are represented as solid spheroids. The arrows indicate the electron flow from the quinone pool to the reduction of extracellular electron acceptors. 


\section{Conclusions}

In contrast with Gram-negative bacteria, for which the understanding of the molecular bases for EET processes is more advanced [7,29], Gram-positive bacteria have a cell surface of very distinct nature composed by a thick peptidoglycan layer $(20-80 \mathrm{~nm})$. In this work, the production and characterization of the key components of the EET pathway of the Gram-positive bacterium T. ferriacetica allowed the preliminary characterization of their electron transfer processes. Indeed, the study of ImdcA and PdcA from T. ferriacetica showed that these proteins have the redox properties necessary to transfer electrons from the quinone pool in the membrane to the cell surface, for the reduction of electron acceptors including iron oxides, electron shuttles or electrodes. In fact, the overall reduction potential window by which these proteins becomes reduced are very similar to those of mesophilic organisms. This probably reflects the thermodynamic constrains given by the potentials of bioenergetic metabolic intermediates (e.g., NADH) and the potentials of the insoluble extracellular acceptors present in the natural environments colonized by these organisms. This study provides guidance for structural biology studies and detailed characterization of the electron transfer processes of these proteins. Only with this information will it be possible to fill in the details that are crucial to capitalize on the advantageous properties of thermophilic organisms to improve BES and increase the production of electricity or other valuable commodities from waste streams.

Supplementary Materials: The following are available online at https:/ /www.mdpi.com/2076-260 7/9/2/293/s1, Table S1: Primers' sequence used in this work, Figure S1: Sequence alignment used to build the CwcA homology based mode, Figure S2: OcwA from T. ferriacetica. Figure S3: SDS-PAGE of (a) ImdcA and (b) PdcA stained with blue-safe, Figure S4: Aminoacid sequence of (a) ImdcA and (b) PdcA, Figure S5: Raw voltammogram obtained by cyclic voltammetry for (a) ImdcA and (b) PdcA.

Author Contributions: Conceptualization, R.O.L. and C.M.P.; Formal analysis, M.M.F., B.M.F., N.L.C., D.L., R.O.L. and C.M.P.; Funding acquisition, R.O.L. and C.M.P.; Investigation, M.M.F., B.M.F., N.L.C., D.L., R.O.L. and C.M.P.; Supervision, C.M.P.; Validation, M.M.F., B.M.F., N.L.C., D.L., R.O.L. and C.M.P.; Visualization, B.M.F., N.L.C., D.L., R.O.L. and C.M.P.; Writing-original draft, M.M.F., B.M.F., N.L.C., D.L., R.O.L. and C.M.P.; Writing-review \& editing, M.M.F., B.M.F., N.L.C., D.L., R.O.L. and C.M.P. All authors have read and agreed to the published version of the manuscript.

Funding: This work was supported by Fundação para a Ciência e a Tecnologia (FCT) Portugal [PTDC/BIA-BQM/30176/2017, Project UIDB/04612/2020, UIDP/04612/2020], and by the European Union's Horizon 2020 research and innovation program under grant agreement No 810856. The NMR data was acquired at CERMAX, ITQB-NOVA, Oeiras, Portugal with equipment funded by FCT, project AAC 01/SAICT/2016.

Data Availability Statement: Not applicable.

Acknowledgments: The authors thank Miguel Teixeira for acquiring the EPR spectra of ImdcA and PdcA and Américo Duarte for the support with the Autolab PGSTAT2014 potentiostat. N-terminal data was obtained by the N-terminal Sequencing Facility at ITQB, while spectrometry data was obtained by the MasSpectrometry Laboratory, Analytical Services Unit at ITQB/IBET.

Conflicts of Interest: The authors declare no conflict of interest.

\section{References}

1. Kumar, A.; Hsu, L.H.H.; Kavanagh, P.; Barrière, F.; Lens, P.N.L.; Lapinsonnière, L.; Lienhard, J.H.; Schröder, U.; Jiang, X.; Leech, D. The ins and outs of microorganism-electrode electron transfer reactions. Nat. Rev. Chem. 2017, 1, 1-13. [CrossRef]

2. Logan, B.E.; Rossi, R.; Ragab, A.; Saikaly, P.E. Electroactive microorganisms in bioelectrochemical systems. Nat. Rev. Microbiol. 2019, 17, 307-319. [CrossRef] [PubMed]

3. Potter, M.C. Electrical Effects Accompanying the Decomposition of Organic Compounds. Proc. R. Soc. Lond. B Biol. Sci. 1911, 84, 571. [CrossRef]

4. Paquete, C.M. Electroactivity across the cell wall of Gram-positive bacteria. Comput. Struct. Biotechnol. J. 2020, 18, 3796-3802. [CrossRef] [PubMed]

5. White, G.F.; Edwards, M.J.; Gomez-Perez, L.; Richardson, D.J.; Butt, J.N.; Clarke, T.A. Mechanisms of Bacterial Extracellular Electron Exchange. Adv. Microb. Physiol. 2016, 87-138. [CrossRef] 
6. Beblawy, S.; Bursac, T.; Paquete, C.; Louro, R.; Clarke, T.A.; Gescher, J. Extracellular reduction of solid electron acceptors by Shewanella oneidensis. Mol. Microbiol. 2018, 109, 571-583. [CrossRef] [PubMed]

7. Louro, R.O.; Costa, N.L.; Fernandes, A.P.; Silva, A.V.; Trindade, I.B.; Fonseca, B.M.; Paquete, C.M. Exploring the Molecular Mechanisms of Extracellular Electron Transfer for Harnessing Reducing Power in METs. In Microbial Electrochemical Technology; Elsevier: Amsterdam, The Netherlands, 2019; pp. 261-293.

8. Nealson, K.H.; Rowe, A.R. Electromicrobiology: Realities, grand challenges, goals and predictions. Microb. Biotechnol. 2016, 9 , 595-600. [CrossRef]

9. Schievano, A.; Pepé Sciarria, T.; Vanbroekhoven, K.; De Wever, H.; Puig, S.; Andersen, S.J.; Rabaey, K.; Pant, D. ElectroFermentation-Merging Electrochemistry with Fermentation in Industrial Applications. Trends Biotechnol. 2016, 34, 866-878. [CrossRef]

10. Mathuriya, A.S.; Yakhmi, J.V. Microbial fuel cells-Applications for generation of electrical power and beyond. Crit. Rev. Microbiol. 2016, 42, 127-143. [CrossRef]

11. Santoro, C.; Arbizzani, C.; Erable, B.; Ieropoulos, I. Microbial fuel cells: From fundamentals to applications. A review. J. Power Sources 2017, 356, 225-244. [CrossRef]

12. Goswami, R.; Mishra, V.K. A review of design, operational conditions and applications of microbial fuel cells. Biofuels 2018, 9 , 203-220. [CrossRef]

13. Koch, C.; Harnisch, F. Is there a Specific Ecological Niche for Electroactive Microorganisms? ChemElectroChem 2016, 3, $1282-1295$. [CrossRef]

14. Wrighton, K.C.; Agbo, P.; Warnecke, F.; Weber, K.A.; Brodie, E.L.; DeSantis, T.Z.; Hugenholtz, P.; Andersen, G.L.; Coates, J.D. A novel ecological role of the Firmicutes identified in thermophilic microbial fuel cells. ISME J. 2008, 2, 1146-1156. [CrossRef] [PubMed]

15. Torres, C.I.; Marcus, A.K.; Parameswaran, P.; Rittmann, B.E. Kinetic experiments for evaluating the nernst-monod model for anode-respiring bacteria (ARB) in a biofilm anode. Environ. Sci. Technol. 2008, 42, 6593-6597. [CrossRef] [PubMed]

16. Lusk, B.G. Thermophiles; or, the Modern Prometheus: The Importance of Extreme Microorganisms for Understanding and Applying Extracellular Electron Transfer. Front. Microbiol. 2019, 10, 818. [CrossRef] [PubMed]

17. Lusk, B.G.; Peraza, I.; Albal, G.; Marcus, A.K.; Popat, S.C.; Torres, C.I. pH Dependency in Anode Biofilms of Thermincola ferriacetica Suggests a Proton-Dependent Electrochemical Response. J. Am. Chem. Soc. 2018, 140, 5527-5534. [CrossRef]

18. Costa, N.L.; Hermann, B.; Fourmond, V.; Faustino, M.M.; Teixeira, M.; Einsle, O.; Paquete, C.M.; Louro, R.O. How Thermophilic Gram-Positive Organisms Perform Extracellular Electron Transfer: Characterization of the Cell Surface Terminal Reductase OcwA. MBio 2019, 10, e01210. [CrossRef]

19. Lusk, B.G.; Badalamenti, J.P.; Parameswaran, P.; Bond, D.R.; Torres, C.I. Draft Genome Sequence of the Gram-Positive Thermophilic Iron Reducer Thermincola ferriacetica Strain Z-0001T. Genome Announc. 2015, 3. [CrossRef]

20. Pankratova, G.; Hederstedt, L.; Gorton, L. Extracellular electron transfer features of Gram-positive bacteria. Anal. Chim. Acta 2019, 1076, 32-47. [CrossRef]

21. Marshall, C.W.; May, H.D. Electrochemical evidence of direct electrode reduction by a thermophilic Gram-positive bacterium, Thermincola ferriacetica. Energy Environ. Sci. 2009, 2, 699-705. [CrossRef]

22. Byrne-Bailey, K.G.; Wrighton, K.C.; Melnyk, R.A.; Agbo, P.; Hazen, T.C.; Coates, J.D. Complete Genome Sequence of the Electricity-Producing “Thermincola potens" Strain JR. J. Bacteriol. 2010, 192, 4078-4079. [CrossRef] [PubMed]

23. Lusk, B.G.; Parameswaran, P.; Popat, S.C.; Rittmann, B.E.; Torres, C.I. The effect of $\mathrm{pH}$ and buffer concentration on anode biofilms of Thermincola ferriacetica. Bioelectrochemistry 2016, 112, 47-52. [CrossRef] [PubMed]

24. Wrighton, K.C.; Thrash, J.C.; Melnyk, R.A.; Bigi, J.P.; Byrne-Bailey, K.G.; Remis, J.P.; Schichnes, D.; Auer, M.; Chang, C.J.; Coates, J.D.; et al. Evidence for direct electron transfer by a gram-positive bacterium isolated from a microbial fuel cell. Appl. Environ. Microbiol. 2011, 77, 7633-7639. [CrossRef] [PubMed]

25. Parameswaran, P.; Bry, T.; Popat, S.C.; Lusk, B.G.; Rittmann, B.E.; Torres, C.I. Kinetic, electrochemical, and microscopic characterization of the thermophilic, anode-respiring bacterium Thermincola ferriacetica. Environ. Sci. Technol. 2013, 47, 4934-4940. [CrossRef] [PubMed]

26. Inoue, K.; Qian, X.; Morgado, L.; Kim, B.C.; Mester, T.; Izallalen, M.; Salgueiro, C.A.; Lovley, D.R. Purification and characterization of OmcZ, an outer-surface, octaheme c-type cytochrome essential for optimal current production by Geobacter sulfurreducens. Appl. Environ. Microbiol. 2010, 76, 3999-4007. [CrossRef] [PubMed]

27. Qian, X.; Mester, T.; Morgado, L.; Arakawa, T.; Sharma, M.L.; Inoue, K.; Joseph, C.; Salgueiro, C.A.; Maroney, M.J.; Lovley, D.R. Biochemical characterization of purified OmcS, a c-type cytochrome required for insoluble Fe(III) reduction in Geobacter sulfurreducens. Biochim. Biophys. Acta Bioenerg. 2011, 1807, 404-412. [CrossRef]

28. Edwards, M.J.; Richardson, D.J.; Paquete, C.M.; Clarke, T.A. Role of multiheme cytochromes involved in extracellular anaerobic respiration in bacteria. Protein Sci. 2020, 29, 830-842. [CrossRef]

29. Costa, N.L.; Clarke, T.A.; Philipp, L.-A.; Gescher, J.; Louro, R.O.; Paquete, C.M. Electron transfer process in microbial electrochemical technologies: The role of cell-surface exposed conductive proteins. Bioresour. Technol. 2018, 255, 308-317. [CrossRef]

30. Xiao, Y.; Zhang, E.; Zhang, J.; Dai, Y.; Yang, Z.; Christensen, H.E.M.M.; Ulstrup, J.; Zhao, F. Extracellular polymeric substances are transient media for microbial extracellular electron transfer. Sci. Adv. 2017, 3, 1-9. [CrossRef] 
31. Pirbadian, S.; Barchinger, S.E.; Leung, K.M.; Byun, H.S.; Jangir, Y.; Bouhenni, R.A.; Reed, S.B.; Romine, M.F.; Saffarini, D.A.; Shi, L.; et al. Shewanella oneidensis MR-1 nanowires are outer membrane and periplasmic extensions of the extracellular electron transport components. Proc. Natl. Acad. Sci. USA 2014, 111, 12883-12888. [CrossRef]

32. Feliciano, G.T.; Steidl, R.J.; Reguera, G. Structural and functional insights into the conductive pili of Geobacter sulfurreducens revealed in molecular dynamics simulations. Phys. Chem. Chem. Phys. 2015, 17, 22217-22226. [CrossRef] [PubMed]

33. Wang, F.; Gu, Y.; O’Brien, J.P.; Yi, S.M.; Yalcin, S.E.; Srikanth, V.; Shen, C.; Vu, D.; Ing, N.L.; Hochbaum, A.I.; et al. Structure of Microbial Nanowires Reveals Stacked Hemes that Transport Electrons over Micrometers. Cell 2019, 177, 361-369.e10. [CrossRef] [PubMed]

34. Carlson, H.K.; Iavarone, A.T.; Gorur, A.; Yeo, B.S.; Tran, R.; Melnyk, R.A.; Mathies, R.A.; Auer, M.; Coates, J.D. Surface multiheme $c$-type cytochromes from Thermincola potens and implications for respiratory metal reduction by Gram-positive bacteria. Proc. Natl. Acad. Sci. USA 2012, 109, 1702-1707. [CrossRef] [PubMed]

35. Marsili, E.; Baron, D.B.; Shikhare, I.D.; Coursolle, D.; Gralnick, J.A.; Bond, D.R. Shewanella secretes flavins that mediate extracellular electron transfer. Proc. Natl. Acad. Sci. USA 2008, 105, 3968-3973. [CrossRef] [PubMed]

36. von Canstein, H.; Ogawa, J.; Shimizu, S.; Lloyd, J.R. Secretion of flavins by Shewanella species and their role in extracellular electron transfer. Appl. Environ. Microbiol. 2008, 74, 615-623. [CrossRef] [PubMed]

37. Newman, D.K.; Kolter, R. A role for excreted quinones in extracellular electron transfer. Nature 2000, 405, 94-97. [CrossRef]

38. Pham, T.H.; Boon, N.; Aelterman, P.; Clauwaert, P.; De Schamphelaire, L.; Vanhaecke, L.; De Maeyer, K.; Höfte, M.; Verstraete, W.; Rabaey, K. Metabolites produced by Pseudomonas sp. enable a Gram-positive bacterium to achieve extracellular electron transfer. Appl. Microbiol. Biotechnol. 2008, 77, 1119-1129. [CrossRef]

39. Milliken, C.E.; May, H.D. Sustained generation of electricity by the spore-forming, Gram-positive, Desulfitobacterium hafniense strain DCB2. Appl. Microbiol. Biotechnol. 2007, 73, 1180-1189. [CrossRef]

40. Edwards, M.J.; White, G.F.; Butt, J.N.; Richardson, D.J.; Clarke, T.A. The Crystal Structure of a Biological Insulated Transmembrane Molecular Wire. Cell 2020, 181, 665-673.e10. [CrossRef]

41. Costa, N.L.; Carlson, H.K.; Coates, J.D.; Louro, R.O.; Paquete, C.M. Heterologous expression and purification of a multiheme cytochrome from a Gram-positive bacterium capable of performing extracellular respiration. Protein Expr. Purif. 2015, 111, 48-52. [CrossRef]

42. Fourmond, V. QSoas: A Versatile Software for Data Analysis. Anal. Chem. 2016, 88, 5050-5052. [CrossRef] [PubMed]

43. Friis, E.P.; Andersen, J.E.T.; Madsen, L.L.; Bonander, N.; Møller, P.; Ulstrup, J. Dynamics of Pseudomonas aeruginosa azurin and its Cys3Ser mutant at single-crystal gold surfaces investigated by cyclic voltammetry and atomic force microscopy. Electrochim. Acta 1998, 43, 1114-1122. [CrossRef]

44. Šali, A.; Blundell, T.L. Comparative Protein Modelling by Satisfaction of Spatial Restraints. J. Mol. Biol. 1993, $234,779-815$. [CrossRef] [PubMed]

45. Palmer, G. The electron paramagnetic resonance of metalloproteins. Biochem. Soc. Trans. 1985, 13, 548-560. [CrossRef] [PubMed]

46. Louro, R.O. Proton thrusters: Overview of the structural and functional features of soluble tetrahaem cytochromes $c_{3}$. J. Biol. Inorg. Chem. 2007, 12, 1-10. [CrossRef]

47. Fonseca, B.M.; Saraiva, I.H.; Paquete, C.M.; Soares, C.M.; Pacheco, I.; Salgueiro, C.A.; Louro, R.O. The tetraheme cytochrome from Shewanella oneidensis MR-1 shows thermodynamic bias for functional specificity of the hemes. J. Biol. Inorg. Chem. 2009, 14, 375-385. [CrossRef]

48. Firer-sherwood, M.; Pulcu, G.S.; Elliott, S.J. Electrochemical interrogations of the Mtr cytochromes from Shewanella: Opening a potential window. J. Biol. Inorg. Chem. 2008, 13, 849-854. [CrossRef]

49. Paquete, C.M.; Louro, R.O. Unveiling the details of electron transfer in multicenter redox proteins. Acc. Chem. Res. 2014, 47. [CrossRef]

50. Reis, C.; Louro, R.O.; Pacheco, I.; Catarino, T.; Turner, D.L.; Xavier, A.V. Redox-Bohr effect in the nine haem cytochrome from Desulfovibrio desulfuricans 27774. Inorg. Chim. Acta 2002, 339, 248-252. [CrossRef]

51. Fonseca, B.M.; Paquete, C.M.; Salgueiro, C.A.; Louro, R.O. The role of intramolecular interactions in the functional control of multiheme cytochromes c. FEBS Lett. 2012, 586. [CrossRef]

52. Mowat, C.G.; Chapman, S.K. Multi-heme cytochromes-New structures, new chemistry. Dalton Trans. 2005, 21, 3381-3389. [CrossRef] [PubMed]

53. Paquete, C.M.; Rusconi, G.; Silva, A.V.; Soares, R.; Louro, R.O. A brief survey of the "cytochromome". Adv. Microb. Physiol. 2019, 75, 69-135. [PubMed]

54. Moser, C.C.; Chobot, S.E.; Page, C.C.; Dutton, P.L. Distance metrics for heme protein electron tunneling. Biochim. Biophys. Acta Bioenerg. 2008, 1777, 1032-1037. [CrossRef] [PubMed]

55. Morgado, L.; Brulx, M.; Pessanha, M.; Londer, Y.Y.; Salgueiro, C.A.; Bruix, M.; Pessanha, M.; Londer, Y.Y.; Salgueiro, C.A.; Brulx, M.; et al. Thermodynamic characterization of a triheme cytochrome family from Geobacter sulfurreducens reveals mechanistic And functional diversity. Biophys. J. 2010, 99, 293-301. [CrossRef] [PubMed]

56. Rodrigues, M.L.; Oliveira, T.F.; Pereira, I.A.C.; Archer, M. X-ray structure of the membrane-bound cytochrome $c$ quinol dehydrogenase NrfH reveals novel haem coordination. EMBO J. 2006, 25, 5951-5960. [CrossRef] 
57. McMillan, D.G.G.; Marritt, S.J.; Firer-Sherwood, M.A.; Shi, L.; Richardson, D.J.; Evans, S.D.; Elliott, S.J.; Butt, J.N.; Jeuken, L.J.C. Protein-Protein Interaction Regulates the Direction of Catalysis and Electron Transfer in a Redox Enzyme Complex. J. Am. Chem. Soc. 2013, 135, 10550-10556. [CrossRef] [PubMed]

58. Saffarini, D.A.; Blumerman, S.L.; Mansoorabadi, K.J. Role of Menaquinones in Fe (III) Reduction by Membrane Fractions of Shewanella putrefaciens. J. Bacteriol. 2002, 184, 846-848. [CrossRef]

59. Lovley, D.R.; Giovannoni, S.J.; White, D.C.; Champine, J.E.; Phillips, E.J.; Gorby, Y.A.; Goodwin, S. Geobacter metallireducens gen. nov. sp. nov., a microorganism capable of coupling the complete oxidation of organic compounds to the reduction of iron and other metals. Arch. Microbiol. 1993, 159, 336-344. [CrossRef]

60. Ehrlich, H.L. Are gram-positive bacteria capable of electron transfer across their cell wall without an externally available electron shuttle? Geobiology 2008, 6, 220-224. [CrossRef]

61. Light, S.H.; Méheust, R.; Ferrell, J.L.; Cho, J.; Deng, D.; Agostoni, M.; Iavarone, A.T.; Banfield, J.F.; D’Orazio, S.E.F.; Portnoy, D.A. Extracellular electron transfer powers flavinylated extracellular reductases in Gram-positive bacteria. Proc. Natl. Acad. Sci. USA 2019, 116, 26892-26899. [CrossRef]

62. Méheust, R.; Huang, S.; Rivera-Lugo, R.; Banfield, J.F.; Light, S.H. Widespread bacterial protein flavinylation in functionally distinct extracytosolic redox biochemistries. bioRxiv 2021. [CrossRef] 